REVISTA DE LITERATURA E CULTURA RUSSA

\title{
O flâneur dostoievskiano: errância e anonimato na capital russa do século XIX
}

Dostoevsky's flâneur: wandering and anonymity in the 19th century Russian capital

Autor: Júlio César Estevam Universidade Federal de Ouro Preto, Ouro Preto, Minas Gerais, Brasil Edição: RUS Vol. 12. No 20

Publicação: Dezembro de 2021 DOI: https://doi.org/10.11606/issn.2317-4765.rus.2021.190683 


\section{O flâneur dostoievskiano: errância e anonimato na capital russa do século XIX}

Júlio César Estevam*

Resumo: Paladino de uma complexa forma de subjetividade que é produto de uma atmosfera psicológica que o insulariza em relação aos demais habitantes das cidades, o flâneur é considerado como sendo uma importante chave de leitura dos processos de modernização dos centros urbanos europeus e de seus desdobramentos. Tendo isso em vista, o objetivo desta pesquisa se concentra, arrazoados os fenômenos sociais às produções literárias oitocentistas, no estudo do flâneur de Dostoiévski. Presente em Pobre Gente, Noites Brancas, A Senhoria, Humilhados e Ofendidos e Crime e Castigo, o flâneur dostoievskiano encerra em si os conflitos, contradições, perspectivas e possibilidades de um período tão peculiar que se incorporou à sua compleição por meio de uma nova e inquietante relação com a cidade moderna.

\begin{abstract}
Agent of a complex form of subjectivity which is the product of an overly psychological atmosphere responsible to keep him isolated from the other modern city-dwellers, the flâneur is, according to this bibliographical research, considered as an important reading key for the modernization of Europeans cities. Afterwards, succeeding the reasoning about the social nineteenth-century literary phenomenon production, the study dives into the ideal conditions to takes into account Dostoevsky's flâneur from Poor People, White Nights, the Landlady, Humiliated and Insulted and Crime and Punishment. the most capable to cover, by himself, the conflicts, contradictions, perspectives and possibilities of a such peculiar time fixed into him as a new and disturbing relationship with the modern city.
\end{abstract}

Palavras-chave: Dostoiévski; Flâneur, Modernidade; Literatura russa moderna; Herói moderno

Keywords: Dostoevsky; Modernity; Flâneur, Modern russian literature; Modern literary hero 
${ }^{*}$ Mestre em Letras pela Universidade Federal de Ouro Preto (UFOP). Graduação em Letras pela Universidade Federal de Minas Gerais (UFMG). Interesse nas inter-relações entre literatura russa, soviética e história, assim como na justaposição entre estética e sociedade moderna, e pelos estudos de Teoria da Literatura, Literatura Comparada e Memória Cultural; http://lattes.cnpq. br/9813715985679439; https:// orcid.org/0000-0003-1272-3743; jc_estevam@hotmail.com

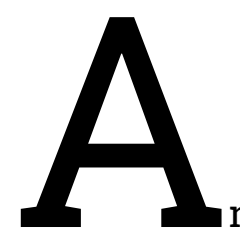

ntes do nascimento de Dostoiévski, o mestre do inaugural imaginário Petersburguês, Gógol, leu E.T.A. Hoffmann e, com ele, aprendeu a combinar o cotidiano opressivo da grande cidade com uma fantasia ilimitada. A Petersburgo de Gógol é uma cidade grandiosa e aterrorizante. Nas palavras de Nabokov, ela é reflexo de um espelho embaçado, uma lúgubre mistura de situações e objetos trocados, recuando, quando mais rápido movem-se para diante, pálidas noites cinzentas, ao invés de negras, e dias negros, ao invés de claros. ${ }^{1}$ Segundo Volkov, essa imagem demoníaca tornou-se mítica. A Petersburgo criada pela imaginação de Gógol não é uma cidade real, mas uma terra de mortos-vivos, um buraco negro que engole pessoas - o Grande Nada - ou "o ápice do vazio", segundo ele próprio. ${ }^{2} \mathrm{Na}$ sua obra, a forte rejeição à cidade, típica da gente comum, vem lenta, mas inexoravelmente à tona, integrando-se ao discurso social e filosófico das camadas instruídas. ${ }^{3}$

Como homem instruído da época, Dostoiévski leu Gógol, e Gógol, Hoffman. ${ }^{4}$ De ambos retirou a doentia, tempestuosa e angustiada forma de narrar a cidade e seus habitantes. Seus personagens são amaldiçoados e, ao mesmo tempo, privilegiados. São os únicos capazes de diferenciarem-se do grande amontoado indiferenciado de homens ao passo que, sensíveis à natureza, ao ritmo da cidade e de seus moradores, se tornam filósofos sem saber. Esse privilégio, cujo ônus é a maldição do reconhecimento da força esmagadora da metrópole, da pobreza das massas, do desejo inalcançável, do amor inverossímil, da solidão como única forma de vida possível, é aclimatado em meio ao ócio e aos vícios urbanos.

\footnotetext{
1 VOLKOV, S. São Petersburgo: uma história cultural. Tradução de Marcos Aarão Reis. Rio de Janeiro: Record, 1997, p. 54.

2 Idem. Ibidem.

3 Idem. Ibidem.

4 Idem, p. 51.
} 
Hoffmann escreveu $A$ janela de esquina do meu primo em 1822. Não se trata de uma narrativa literariamente icônica do ponto de vista da recepção crítica, mas ganhou notoriedade, sobretudo, por ter-se engajado criticamente quanto ao contexto demasiadamente marcado pelos usos dos espaços públicos urbanos, como sendo um costume hegemônico, massificador. O breve ínterim é narrado à perspectiva de um jovem que visita seu primo e com ele passa algumas horas a espreitar, acipitrino, os habitantes da cidade pela janela de um quarto, na esquina de uma rua limítrofe a uma movimentada feira urbana. Ali, vende-se de tudo, e todos os tipos urbanos são postos em evidência, como em uma enorme vitrine a céu aberto.

Quando inquerido acerca do controverso prazer de sentar-se à janela e observar aquele grande agrupamento de pessoas que a olhos pouco treinados causava vertigem, o primo responde ao narrador zombando de sua falta de sensibilidade, pois as grandes massas eram, para ele, toda a sua fonte de inspiração. $\mathrm{Na}$ tentativa de dirimir-lhe de sua insensibilidade e ensinar-lhe as primícias da arte de enxergar, como apenas um flâneur é capaz de fazer, o observador pede ao jovem narrador para que pegue uma luneta e olhe diretamente para baixo, para a feira intensamente movimentada. Enquanto se entretêm com as cenas daquele variado cenário da vida burguesa, ${ }^{5}$ aproveitam para descrever as personagens que vão abrindo caminho às cotoveladas. Em meio à profusa multidão, os homens e mulheres que se deslocam pela feira agem como se não pudessem ser vistos, por isso são flagrados cometendo pequenas trapaças, seduzindo e sendo seduzidos, pechinchando, roubando e sendo postos a pedir esmolas, depois subtraídas sem pejo.

Na França, segundo Benjamin, ${ }^{6}$ o conto de Hoffmann alcançou um grande êxito, pois tinha-se, àquela ocasião, uma compreensão particular para com esse tipo urbano, o flâneur. Forjado no seio da recém-formada burguesia do século XIX e da grande multidão se distinguindo em virtude de sua rela-

5 Idem, p.16.

6 BENJAMIN, W. Obras escolhidas III. Tradução de José Carlos Martins Barbosa e Hemerson Alves Baptista. São Paulo: Editora Brasiliense, 1989. p. 46. 
ção com o espaço urbano, o flâneur pôde, segundo Elizabeth Wilson, ${ }^{7}$ tornar-se importante chave de leitura do processo de modernização dos centros urbanos europeus e de seus desdobramentos.

Embora já houvesse se tornado figura conhecida na Paris oitocentista, foi um panfleto anônimo de 1806 o responsável por fundar, ainda que obliquamente, o precursor do ethos mais peremptório do flâneur, que só iria se consolidar de maneira definitiva meio século mais tarde. O panfleto intitulado Le Flâneur au salon ${ }^{8}$ relata um dia da vida de Monsieur Bonhomme, um desocupado da era Bonaparte que, além de vagar sozinho e aleatoriamente por Paris desfrutando-a à vontade, está, indelevelmente, anexado à sua, quase total, não aderência à metrópole, de modo que se mantêm num paradoxal entre lugar: está dentro e fora da cidade. Dentro porque, produto de seu meio, literalmente, a habita. Fora porque tornara-se dela um ente oculto, um arguto e onipresente observador.

Tipo singular, incondicionalmente reservado ao sujeito urbano, o flâneur foi além de objeto de estudo posterior de inúmeros ensaístas, material de inspiração para a fixação de seu mais proeminente arquétipo em $A$ fisiologia de um flâneu, $r^{9}$ texto datado do fim da primeira metade do século XIX e no qual debuta-se o flâneur ${ }^{10}$ como membro radicado e definitivo no meio burguês. Sua inação conspícua, tão frequentemente associada à vagabundagem, foi ao longo da Monarquia de Julho, período histórico francês que durou cerca de dezoito anos, relacionada a um comportamento superior, próprio dos intelectuais de seu tempo. Em síntese, esse trabalho intelectual é o que diferencia o flâneur do ocioso vagabundo - sua indolência é apenas aparente, pois segundo nos diz o capítulo quinze ${ }^{11}$ da Physiologie du flâneur, ele está sempre ocupado com a realização de seu principal ofício, por isso, não apenas olha, mas

7 WILSON, E. O flâneur Invisível. Uberlândia: Artcultura, v.7, n. 11, 2005. p. 154.

8 Idem, p. 83.

9 HUART, L. Physiologie du flâneur. Paris: Aubert et Cie, 1841.

10 Idem.

11 HUART, L. Physiologie du flâneur, Paris: Aubert et Cie, 1841. 
observa, estuda, analisa. Ele é, em suma, um philosophe sans le savoir - um filósofo sem o saber - e possui uma característica distintiva do verdadeiro homem das letras.

Hoffman, assim como Baudelaire, foi arquétipo de um flâneur e em nenhum outro trabalho conseguiu, como em $A$ janela de esquina do meu primo, assim monumentalizar-se. No conto, publicado um ano depois do nascimento de Dostoiévs$\mathrm{ki}$, revezam-se, como no esquema de um espetáculo teatral, as falas dos primos entremeadas por trechos em discurso direto..$^{12}$ Esse recurso e a importância que é dada à visão parece, em certo sentido, ter sido reaproveitado por Dostoiévski, em Pobre Gente. ${ }^{13}$

Romance epistolar - primeiro romance escrito por Dostoiévski -, em Pobre Gente são apresentadas aos leitores muitas das figuras, cenas e ambientações que se tornarão recorrentes em sua obra. O protagonista, Makar, é um velho escriturário, modesto de posses, porém ternamente devotado ao próximo, a quem ama e socorre nas horas de aflição. Ele vive, como vivem outras personagens de Dostoiévski, em uma pensão, na companhia de gente muito humilde ou desempregada. Quase que diariamente corresponde-se por cartas com uma jovem, sua parente distante, Várienka. Estas duas criaturas, sozinhas no mundo e à margem da sociedade burguesa, dedicam-se ao amparo mútuo, ao socorro às vezes material, na medida daquilo que lhes é permitido, em virtude de sua, igualmente, frágil condição. $O$ enredo é bastante simples, mas os personagens coadjuvantes e suas histórias, assim como a degradação moral, os vícios, o sentido dado à vida e a elevada compreensão dos desígnios e misericórdia de Deus, serão revisitados mais adiante por Dostoiévski e ganharão dimensões mais robustas em outras narrativas.

Makar, embora quase não saia de seu apartamento, é um flâneur. O flâneur dostoievskiano difere um pouco de seu mo-

12 HOFFMANN, E.T.A. A janela de esquina do meu primo. Tradução de Maria Aparecida Barbosa. São Paulo: Cosacnaify, 2010. p. 29.

13 DOSTOIÉVSKI, F. Pobre gente. Tradução de Natália Nunes. Rio de Janeiro: Aguilar editora, 1963. 
delo ocidental. Não há compromisso com o "ócio", às vezes, entorpecedor. Embora pareçam perder tempo vagando pelas ruas, as personagens dostoievskianas quase sempre possuem empregos formais. Seus flâneres não deambulam apenas fisicamente, descortinando espaços públicos por eles mapeados, guardados com carinho, como se se tratasse de lugares nos quais vivenciaram grandes paixões ou momentos de singular contemplação. O flâneur doistoievskiano, sobretudo em Pobre Gente, Noites Brancas e Crime e Castigo, é mental. Suas errâncias podem ser produto de uma imaginação exacerbada ou demência, por isso nunca se sabe ao certo como caracterizar seus trânsitos. Tudo o que ocorre é fragmentário, triste e sem sentido, mas está sempre irradiado pela esperança ou pela recordação. ${ }^{14}$ Suas experiências, a saber, quer sejam na rua, quer sejam em casa, sempre parecem oníricas, fantasiosas, embora, paradoxalmente, Dostoiévski possua um forte comprometimento com a realidade.

Embora muitos dos praticantes da flânerie dostoievskiana sejam parcialmente mentais, Makar o é por completo. Sabe de tudo, observa tudo, como um prototípico flâneur, entende tudo, tem um conselho para dar sobre tudo, sem, no entanto, ir à rua, à feira, ao mercado ou arvorar-se, como quem se autoproclama portador da verdade. O herói dostoievskiano é, como Makar, um esforçado, útil no sentido mais compassivo da expressão. Doa-se integralmente às suas causas e aos seus projetos, às vezes chegando à loucura, a agudas formas de violência e torturas mentais.

Poderosamente melancólicas, as narrativas dostoievskianas nas quais se flagra a figura do flâneur exibem um indivíduo problemático, guiado por um ideal incompatível com a realidade imediata, por isso, sem eficácia, tenta reconciliar sua interioridade com a realidade concreta, porém, embora penosamente se empenhe, não se acomoda em parte alguma. É preciso errar por descaminhos a fim de reconhecer-se como identidade, como parte do mundo que, paradoxalmente, ama e odeia com igual intensidade. A modernidade ocidental

14 LUKACS, G. A teoria do romance. Tradução de José Marcos Mariani de Macedo. São Paulo: Editora 34, 2000. p. 133. 
chega até eles de maneira precária e, a ela, esses flâneres reagem com desagrado, tentativas frustradas de entendimento, inconformidade e, sobretudo, incompatibilidade. Tentam tirar algum proveito das circunstâncias tais como se apresentam, tentam entender como funcionam tais novidades, empenham-se na realização de suas tarefas pragmáticas, dizem, em alguns casos, gozar na execução de suas atividades, porém sua felicidade é sempre breve e improcedente, alvejada pela escuridão e pelo tédio. Se o céu se enche de luz, se há uma réstia de esperança em dias melhores, mais belos, os flâneres dostoievskianos, assim como Makar, cavalgam o Pégaso ${ }^{15}$ e se perguntam, ao relancear a vista à volta e tornar a encontrar tudo como antes... cinzento e insípido: De onde procedeu toda essa alegria? Por todo lado as mesmas manchas de tinta, as mesmas mesas, os mesmos papéis e sua própria imagem, tal qual se lhe afigurava antes. (DOSTOIÉVSKI, 1963).

Embora não seja um solitário tão conservador como o Sonhador de Noites Brancas, ${ }^{16}$ Makar é solitário em seus pensamentos. É muito parecido com Akaki, de O Capote. Embora trabalhe, desfrute da companhia (jocosa) de alguns colegas que $o$ humilham quase que diariamente, está irremediavelmente só em seus pensamentos, que perambulam às soltas. Sua modesta condição não é compatível com seus gostos refinados, mantidos cuidadosamente, procedendo, no tocante a eles, como um avarento com seu tesouro, ${ }^{17}$ como recorrentemente o fazem os heróis de Dostoiévski. Makar vive em um apartamento cujo andar é mais elevado em relação ao andar habitado por sua única interlocutora, uma jovem chamada Varvara, sua parente, em um prédio contíguo. Através das cortinas, plantas e abajures, podem entender-se mutuamente, comunicando-se por meio de pequenos gestos.

15 DOSTOIÉVSKI, F. Pobre gente. Tradução de Natália Nunes. Rio de Janeiro: Aguilar editora, 1963. p. 169.

16 DOSTOIÉVSKI, F. Noites Brancas. Tradução de Nivaldo dos Santos. São Paulo : Editora 34,2007 . p. 30.

17 BENJAMIN, W. Obras escolhidas III. Tradução de José Carlos Martins Barbosa e Hemerson Alves Baptista. São Paulo: Editora Brasiliense, 1989. p. 78. 
Em Pobre Gente, Makar vê o mundo pela janela e a ele reage por meio das cartas que escreve e endereça diariamente à jovem. Tais cartas metaforizam as ruas. Através delas o leitor tem acesso às suas andanças, às humilhações pelas quais passa, ao histórico das compras que faz em benefício de sua interlocutora, ao frio que sente, às vestes andrajosas que usa. Seus pensamentos são, em tudo, opostos ao pragmatismo do pensamento moderno. Seu hábito de escrever evidencia essa anacronia e salienta a disponibilidade de tempo, tempo que ele suspende e do qual dispõe como um flâneur. Suas conversas são quase sempre epistolares e repletas de sentido literário, de vivacidade e de um forte entendimento da vida, das relações para além daqueles muros, quartinhos separados de cozinhas por biombos improvisados e falsos benfeitores. $O$ flâneur dostoievskiano em Pobre Gente é um esfarrapado, um deserdado da sorte, sobre o qual paira uma atmosfera taciturna que o acompanha ao longo de toda a narrativa, que desemboca, evidentemente, num triste desenlace.

Tal qual ocorre ao Sonhador de Noites Brancas, cuja solidão desalentadora é inevitável, Makar também termina só. Em certa altura, um aristocrata propõe casamento a Varvara, que o aceita. Trata-se, para ela, de uma chance única, por isso despede-se de seu prestativo interlocutor, cujo prazer pela escrita manifestado naquelas longas e cotidianas cartas será, inevitavelmente, interrompido. Makar, em vão, tenta dissuadi-la de sua decisão, de um sacrifício que poria fim à ingenuidade da jovem com a qual, por tanto tempo, correspondera-se. As reticências com as quais finaliza a carta, para a qual não obteve resposta, metaforizam, às margens do urbanismo moderno, a solidão do vazio que está por vir em um espaço cênico indispensável para o flâneur de Dostoiévski. Ali, sobretudo na periferia ou na mixórdia dos casarões habitados, no centro, por toda sorte de tipos humanos, se desenrolam e se enovelam tramas. A ocupação desses espaços e uma singular apropriação dos espaços públicos remetem, em alguns casos, a uma voluntária desorientação espacial com a qual, num espaço-tempo distinto do ordinário, o flâneur dostoievskiano experiência a singularização das percepções sensoriais. Por isso, ainda que 
repleto de afazeres, Makar dispõe de tempo, do qual lança mão em benefício de sua interlocutora e em seu próprio. Por isso, o narrador de Noites Brancas, um jovem Sonhador de 26 anos, suspende o tempo e vive vagaroso como uma tartaruga, ${ }_{1}^{18}$ pondo-se a deambular, sensível, abnegada e compassivamente, pela capital russa do século XIX.

Em Noites Brancas, o autor "confia" a visão de São Petersburgo a "um pedestre, um flâneur, ${ }_{1}^{19}$ um indivíduo "puro" e observador que se destaca em meio aos seus correlatos ociosos graças a uma visão muito sutil e emocionalmente sensível, que muitas vezes o leva a vivenciar "catástrofes" internas. ${ }^{20}$

Narrativa que tornou-se um ícone do surreal e do romântico na literatura russa dos anos de 1800, Noites Brancas ${ }^{21}$ foi escrita nos primeiros anos de atividade de Dostoiévski como escritor. Seu narrador-personagem é um solitário crônico, não fala com ninguém e ninguém sente sua falta. Caminha pela cidade e rapidamente, sem dar-se por isso, cumpre grandes distâncias. ${ }^{22} \mathrm{~A}$ não ser por um fluxo de imagens que se misturam caoticamente e se sobrepõem umas às outras, ele pouco vê, "objetivamente", da metrópole inenarrada por Dostoiévski.

Segundo Turbanov, ${ }^{23}$ a observação é inerente ao verdadeiro flâneur, sobretudo relevante quando a clara hierarquia que organiza o mundo desaparece, como ocorre, por exemplo em Noites Brancas. No momento em que o mundo se transforma em um amontoado caótico de coisas, cujo modelo é uma lojinha de bugingangas, há a necessidade de uma acuidade visual

18 DOSTOIÉVSKI, F. Noites Brancas. Tradução de Nivaldo dos Santos.São Paulo : Editora 34, 2007. p. 30.

19 TURBANOV, I. Flaneri N. Gogolya i F. Dostoevskogo. Literaturno-filosofski zhurnal. Disponível em: https://www.topos.ru/article/literaturnaya-kritika/flanery-n-gogolya-i-f-dostoevskogo. Acesso em: 5 jun. 2021.

20 Idem.

21 DOSTOIÉVSKI, F. Noites Brancas. Tradução de Nivaldo dos Santos. São Paulo: Editora 34, 2007.

22 Idem. p.15.

23 TURBANOV, I. Flaneri N. Gogolya i F. Dostoevskogo. Literaturno-filosofski zhurnal. Disponível em: https://www.topos.ru/article/literaturnaya-kritika/flanery-n-gogolya-i-f-dostoevskogo. Acesso em: 5 jun. 2021. 
especial ${ }^{24}$ Essa acuidade visual pode muito bem ser atribuída ao flâneur dostoievskiano, que vê além da ordem visível e do caos da cidade mais "fantástica" da Rússia, ${ }^{25}$ materializada pelas mãos de Dostoiévski.

Afastado do real, poeta e jovem sentimental, o herói de Noites Brancas também é um flâneur dostoiévskiano. Embora sua visão, despojo de seus correlatos ocidentais àquela altura em relativo desuso, alcance distâncias tremendas, o brumado horizonte petersburguês lhe impõe e ao leitor um desafio: repleto de largas e extensas avenidas, ele é, paradoxalmente, curtíssimo, indecifrável, por isso inenarrado, sob uma atmosfera diabólica, úmida e doentia. Nesse cenário, apenas um bom flâneur, inculto no sentido de que sabe tirar proveito da cidade sem, contudo, tornar-se parte dela (fixar-se nela), mas no caos, no transitório e no fugidio, pode, como o dostoievskiano, enxergar através desse horizonte embaciado pelo qual também, vagarosamente, desliza. Nas palavras do filólogo russo Igor Turbanov ao retomar M. Yampolsky, ${ }^{26}$ o flâneur é o responsável por receber a função não apenas de observar e contar histórias, mas de decodificar, como um detetive, a cidade disfarçada. Na qualidade de decodificador, detetive e andarilho preguiçoso, graças ao seu olhar agudo e tenaz, o flâneur se torna um colecionador, e colecionador de todos os tipos de "migalhas semântico-simbólicas". ${ }^{27}$

Os heróis de Dostoiévski possuem, ainda segundo Turbanov, as propriedades notáveis de um flâneur [...] Embora lentos, eles avidamente agarram impressões instantâneas e as transferem imediatamente para o seu mundo íntimo, onde dissecam essas "migalhas" de realidade com uma espécie de prazer masoquista. ${ }^{28}$ Sobretudo masoquista, porque, como é a sua visão interior a que mais prevalece e mais fundo se enraíza no mundo íntimo do herói, mais trágico e catastrófico se torna

24 Idem.

25 Idem.

26 Idem.

27 Idem.

28 Idem. 
o seu mundo exterior (TURBANOV, 2011). Ao colecionar bagatelas produzidas e descartadas, como mercadorias, em tempo aceleradíssimo, o reativo e "anacrônico" flâneur desloca-se num tempo diverso do habitual. Seu movimento pressupõe uma nova relação espacial e temporal. Seu estado de espírito está, constantemente, vagaroso, ainda que se desloque rapidamente. A lentidão do Sonhador não se refere a uma temporalidade absoluta e objetiva, mas sim relativa e subjetiva, ou seja, significa uma outra forma de apreensão e percepção do espaço urbano que vai bem além da representação meramente visual. Para Deleuze e Guattari, a lentidão não seria, como se pode acreditar, um grau de aceleração ou desaceleração do movimento, do rápido ao devagar, mas sim um outro tipo de movimento. ${ }^{29}$ Esse tipo de movimento está, em tese, associado à capacidade de suspensão do tempo. Em Noites Brancas, o narrador-personagem é, assim como Makar, de Pobre Gente, exímio em sua capacidade de suspendê-lo, desacelerando-o, subjetivamente, ao passo em que se perde pela cidade que tão bem conhece, transformando-a em um espaço que fala direta e individualmente ao seu coração.

Como um romancista, um poeta, o flâneur dostoievskiano de Noites Brancas cria romances inteiros, histórias, em seus devaneios, tanto que não se sabe, de fato, se vivencia tudo aquilo que narra ou se tudo aquilo que narra, ou parte daquilo que narra é produto de uma mente criativa e oposta à objetividade e ao racionalismo modernos. Sua profunda e solene relação com a literatura e com as artes, no geral, é compartida com Makar, de Pobre Gente, e Ivan, de Humilhados e Ofendidos. Vivem, os três, enquanto ainda habitam os muros da cidade, um mundo diverso do ordinário, oculto sob o brumado golfo finlandês. Sua singular e superlativa "capacidade e vontade de permanecer tanto dentro quanto fora do inferno" ${ }^{\prime 30}$ faculta ao flâneur a preservação de sua subjetividade, ao passo que a dos outros é convertida em produto. Essa pária existência permite a ele não apenas a manutenção de sua subjetividade,

29 BERENSTEIN, P. Elogio aos Errantes. Salvador: Editora EDUFBA, 2012. p. 286.

30FERGUSON, P. Paris as revolution: writing the nineteenth-century city. University of California Press, Berkeley, 1994. p. 91. 
mas uma existência "para-real", pois o flâneur, em seu mundo particular, no entanto paralelo ao real, pode viver como melhor lhe apraz. Ali, contempla tudo aquilo que no mundo real pode apenas olhar.

Quando digo, "olha" estou mentindo: ele não olha, mas contempla como que inconscientemente, como se estivesse cansado ou ocupado naquela mesma hora com alguma outra coisa, um objeto mais interessante; tanto que apenas de modo fugaz, quase sem querer, ele pode conceder tempo a tudo em redor. ${ }^{31}$

De fato, a contemplação dá-se em outra dimensão, posto que apenas na para-realidade o flâneur pode suspender o tempo ${ }^{32}$ prefixado alguns séculos antes quando, observou o historiador Lynn White, nenhuma comunidade da Europa sentia que poderia manter a cabeça erguida a não ser que no meio dela os planetas girassem em ciclos e epiciclos, enquanto os anjos trombeteassem, os galos cantassem, e os apóstolos, reis e profetas marchassem para a frente e para trás ao ribombar das horas. ${ }^{33}$

O mundo habitado pelo flâneur de Dostoiévski é, em Noites Brancas, diverso do habitual. Está encerrado em si mesmo e só faz concessões parciais a Nástienka, sua única interlocutora. Afora o comportamento dela, mais pragmático do que o de seu sonhador interlocutor, tudo ali funciona sobrenaturalmente, oculto por um véu de onírica imprecisão. Por isso, às vezes questiona-se a existência de Matriôna, personagem que, em Noites Brancas, entra e sai do quarto habitado pelo Sonhador, sobretudo quando está prestes a dormir ou acordar, mal dirigindo-se a ele. Na verdade, toda a narrativa pode, em outra perspectiva, ser lida como um produto onírico em virtude da nebulosidade de suas espectrais locações cambiantes, postas quase lado a lado e narradas, à moda de Gógol, muito rapidamente. "Em Petersburgo", diz o Sonhador, "existem recantos

31DOSTOIÉVSKI, F. Noites Brancas. Tradução de Nivaldo dos Santos. São Paulo: Editora 34, 2007. p. 33.

32 Idem. Ibidem.

33 Lynn White Jr. Medieval Technology and Social Change. Nova Iorque: Oxford university press, 1964. p. 124. 
bastante estranhos. Nesses lugares parece que não penetra aquele mesmo sol que brilha para todos os petersburguenses, mas sim um outro, novo, enviado como que de propósito para esses recantos, e que brilha com uma luz diferente e particular" ${ }^{34}$ Sua loquacidade está em sintonia com o mundo "para-real" no qual vive e segundo o qual, há tempo de sobra para que tudo seja dito e explicado, minuciosamente. Ali, o flâneur pode dar tempo a tudo enquanto, habilmente, fixa as fisionomias das pessoas com as quais estabelece contato revelando sua capacidade de converter-se em espião. Como um antissocial insondável, incognoscível, ele vê tudo e todos, mas poucos, raros ou inexistentes, são aqueles que o podem ver, inculto, em meio à multidão de passantes.

Além da capacidade de se perder e de, ao mesmo tempo, deslocar-se demoradamente pelo espaço urbano reconfigurando-o segundo suas próprias inclinações poéticas, a solidão do flâneur dostoievskiano é superior, singular. Em Noites Brancas, ela é tão preponderante que o leitor, como dito anteriormente, às vezes questiona a existência das demais personagens, tão artificiais se parecem quando contrastadas à grandiosa insularidade da condição do Sonhador. Essa condição é prerrogativa para a existência do flâneur, mas, como se sabe, funciona em dois sentidos: há a solidão que figurava como item fundamental para a garantia de sua privacidade e de sua liberdade individual e há a solidão que é sua corolária relações sociais frouxas e completa desconexão de tudo o que deveria ligar o flâneur dostoievskiano à sociedade. A segunda o desagrada, mas é consequência inalienável da primeira. A erosão dos laços sociais a que está exposto obnubila sua própria existência, por isso ele "vagueia no espaço até encontrar um "desconhecido familiar" (YAMPOLSKY, 2000), como ocorre, por exemplo, no episódio em que diz conhecer todos os moradores da cidade sem, contudo, com eles estabelecer quaisquer relações. ${ }^{35}$ Assim e só assim pode certificar-se de que está vivo. $\mathrm{Na}$ ausência de tais desconhecidos familiares, como às

34DOSTOIÉVSKI, F. Noites Brancas. Tradução de Nivaldo dos Santos. São Paulo: Editora 34, 2007. p. 30.

35 Idem. p. 12. 
pessoas com as quais o Sonhador eventualmente se encontra, segundo Turbanov, o herói de Dostoiévski se apropria de uma consciência panorâmica, que é em grande parte orientada pela necessidade de ligar o visível à imagens da memória. ${ }^{36}$ Por isso, em tese, ele está tão familiarizado com as casas e suas cornijas a ponto de com elas entabular conversa, ${ }^{37}$ fazem parte de sua memória afetiva e dizem diretamente ao seu coração, atestam em favor de sua existência.

Em sua inesperada interlocução com Nástienka, o flâneur dostoievskiano de Noites Brancas se queixa de seu vagar melancólico, mas também prazeroso. Como que antevendo o prenúncio de um desfecho triste, anuncia que, ao lado dela, não deseja pensar no futuro, pois no futuro antevê a solidão e uma vida inútil cheirando a mofo. ${ }^{38}$ De fato, o Sonhador está correto. Suas relações são frouxas, muito porosas. A ansiedade de sua presença não oculta sua escassez de juízo e traquejo social. Quer tudo, oferece tudo, ainda que, objetivamente, nada possa oferecer ou receber daqueles estranhos e, acima de tudo, temporários - porque tudo ali é impermanente -, familiares passantes.

Embora também defina a si mesma como sendo sonhadora, Nástienka, assim como Várienka, é pragmática, toma decisões mais acertadas e simples, e em sua simplicidade conecta-se mais efetivamente com o mundo real, o que, segundo Nivaldo dos Santos, ${ }^{39}$ a torna capaz de ajustar-se minimamente ao ritmo da vida cotidiana. Seus sonhos, segundo o tradutor, não vão muito além do mundo à sua volta, ela não tem grandes ambições; na verdade, deseja apenas casar-se com o homem que ama e, infelizmente, para o Sonhador, o homem a quem ama é outro. Sentindo-se prestes a ser abandonado por Nástienka, o Sonhador declara seu amor. Nástienka aceita-o, com

36TURBANOV, I. Flaneri N. Gogolya i F. Dostoevskogo. Literaturno-filosofski zhurnal. Disponível em: https://www.topos.ru/article/literaturnaya-kritika/flanery-n-gogolya-i-f-dostoevskogo. Acesso em: 5 jun. 2021.

37 DOSTOIÉVSKI, F. Noites Brancas. Tradução de Nivaldo dos Santos. São Paulo : Editora 34, 2007. p. 13.

38 Idem, p. 42.

39 Idem, p. 86. 
ele faz planos de casamento e de uma vida repleta de prazeres simples que muito o agradam. Embora não se sinta absolutamente convencido de que ela possa ser capaz de o amar, o solitário Sonhador de Noites Brancas a tudo aceita e comemora, mas sua felicidade dura pouco. A solidão lhe é inerente. Nástienka lhe escapa dos dedos. De fato, ele nunca a possuiu, assim como nunca possuiu coisa alguma senão um pequeno quarto verde (ao qual se refere como sendo um casco de tartaruga que de tudo o pode proteger) e uma janela voltada para uma triste casa amarela que, àquela ocasião, pareceu-lhe ainda mais velha e feia, assim como o futuro por ele antevisto e metaforizado na luz embaciada do sol e na decrepitude dessa casa de cornijas enegrecidas e paredes manchadas.

Alheio a tudo e a todos, os dramas do flâneur dostoievskiano de Noites Brancas não afetam o mundo à sua volta, nem mesmo o da própria Nástienka; de certo modo, até esse drama adquire um caráter imaginário, o que reforça o isolamento desse indivíduo romântico em relação à sociedade, cada vez mais alicerçada sobre a lógica do pragmatismo e da temporalidade objetiva das relações, do tempo e do espaço que o desloca, empurrando-o para as margens do urbanismo moderno.

Assim, Noites Brancas não deixa de tocar no drama do pequeno individuo (malienki tcheloviek) que encontra a satisfação de seus modestos desejos apenas através do sonho. Podemos até dizer que, fora do mundo imaginário, esse indivíduo não chega sequer a possuir uma existência concreta; note-se, aliás, que em momento algum da narrativa ele é nomeado. Sua imagem possui, desse modo, a mesma natureza fantasmagórica daquela cidade fantástica que ele habita e dos espectros que habitam os seus sonhos. ${ }^{40}$

O espectral, a melancolia, o onírico e a natureza fantasmagórica da capital russa do século XIX impregnam os heróis de Dostoiévski até a medula. Esse espaço, tal qual narrado por ele e experimentado diuturnamente por suas personagens, é, dentre tantos espaços maiores e menores, extremamente notável. Embora seus heróis possam, assim como Makar, se isentar de narrá-los, sua natureza é tão magnânima que inva-

40 Idem. Ibidem. 
de os aposentos por eles habitados e ali, no interior doméstico, encarrega-se de esculpir as feições do que está fora, ao mesmo tempo em que, tendo-as esculpido, viaja no sentido oposto, esculpindo fora o agravamento daquilo que ela mesma inculcou. Desagregados uns dos outros, de uma relação comum e mais profunda, abnegada com a comunidade, com a arte, com a fé, os heróis dostoievskianos perambulam pelas ruas e disparam pensamentos, como se fossem morteiros. Sua existência ultraja, está na contramão e apenas o leitor é capaz de entendê-los e aos grandes e pequenos crimes por eles, eventualmente, cometidos. A modernidade desagregou-os uns dos outros, tornou-os vaticínios do caos, da morte, da solidão inescapável, da tristeza irremediável.

À medida em que as tradicionais forças de coesão eram erodidas pela modernidade, pela desintegração cultural, também tornavam-se inúteis os esforços de congregação. Dentre todos os escritores russos, Dostoiévski foi quem menos creditou importância a eles. Reconheceu os vícios, reconheceu a derradeira condição humana sem, contudo, opor-se a ela, sem propor-lhe, como Tostói, uma solução política e prática. Apenas a fé tardia, a dor e a miséria libertariam o homem do ultraje que a modernidade, em tese, potencializou ao desconectá-lo do destino apoteótico propalado pela antiguidade. Em Dostoiévski, as cidades, as casas, os apartamentos, os destinos dos homens são sempre obscuríssimos, melancólicos; fantasmagorias daquilo que vivenciam diariamente. Dos romances de Dostoiévs$\mathrm{ki}$, A Senhoria foi, embora pouco lida e muito frequentemente objeto de crítica negativa, a que melhor se encarregou de recuperar o misterioso, o mundo inconsciente - tão pouco prestigiados à época, a não ser talvez por Dostoiévski -, assim como posicionar-se contrariamente ao materialismo que norteara as produções literárias em fins do século XIX.

Em A senhoria, o flâneur de Dostoiévski é o único dos heróis dostoievskianos a ver-se às voltas com a materialização do mundo sobrenatural, da feitiçaria, do misterioso. Ele é, não por acaso, como todo flâneur, um cientista. Cético e muito erudito, o flâneur dostoievskiano de A Senhoria é devorado por "uma paixão, uma dessas paixões fundas e insaciáveis que conso- 
mem toda a existência de um homem e que, para as criaturas do temperamento de Ordínov, são absorventes, não lhes dando ensejo a que conheçam outras esferas da vida. Essa paixão era a ciência". ${ }^{41}$

Morador de Petersburgo, vivendo àquela ocasião, como se fosse um completo forasteiro, isolado do mundo e sem estabelecer quaisquer relações que fossem, ${ }^{42}$ Ordínov "obedecia a um impulso inconsciente, uma sede de aprender, indagar, pesquisar, entesourar conhecimentos no seu espírito, sem objetivo ou razões determinadas". ${ }^{43}$ Rapaz pobre, como o sem número de deserdados da sorte, heróis dostoievskianos, Ordínov compraz-se sobremaneira no capital - a ciência -, que para ele configura, à perspectiva do narrador, uma arma contra ele próprio apontada. ${ }^{44}$ À margem da existência ruidosa e matizada da sociedade, como se esse afastamento permitisse a ele conservar intacto o interesse pelo saber escolástico, Ordínov evitava, ao máximo, sair à rua, e foi com pesar que abandonou, definitivamente, por ocasião de um imprevisto da senhora que até aquele momento o pudera alojar, o quarto a que já se afeiçoara. Assim como Makar, de Pobre Gente, e o Sonhador, de Noites Brancas, Ordínov, desde que pudesse, no quarto, flanar à vontade, preferia sua quietude à mixórdia das ruas, por isso, muito a contragosto, vendo-se obrigado a procurar por um novo quarto, pôs-se a vagar pela capital russa do século XIX.

Aquela vagabundagem a que agora se entregava causava-lhe uma sensação de alegria, despertando o seu interesse. Olhava para tudo e prestava atenção a tudo o que ouvia. ${ }^{45}$

41 DOSTOIÉVSKI, F. Noites Brancas e Outras Histórias. Rio de Janeiro: José Olympio, 1962. p. 328.

42 Assim como o Sonhador de Noites Brancas, o flâneur dostoievskiano de $A$ senhoria não tivera ocasião de criar estima por alguém e "quando, sob qualquer pretexto, dirigia-se a algum transeunte, este o olhava com espanto, de modo peculiar. Parecia-lhe que o tomavam por louco ou, pelo menos, por um excêntrico, o que no fim de contas vinha a dar no mesmo." 43 DOSTOIÉVSKI, F. Noites Brancas e Outras Histórias. Tradução de Vivaldo Coaracy. Rio de Janeiro: José Olympio, 1962. p.328.

44 Idem. Ibidem.

45 Idem, p. 329. 
Na exuberância do mundo material, Ordínov procurou a prova da exatidão das conclusões a que havia chegado no silêncio de suas noites solitárias. "Olhava para tudo e prestava atenção a tudo o que ouvia. Ao mesmo tempo, de acordo com a sua maneira de ser, lia entre os quadros que seus olhos contemplavam como costumava ler entre as linhas do que está escrito num livro. Tudo lhe causava uma impressão distinta, e nenhuma impressão lhe escapava. Com um olhar pensativo examinava a fisionomia dos que passam; escutava o rumor das conversações [...] Pequenos incidentes a que ninguém prestaria atenção, surpreendiam-no e lhe inspiravam novas ideias" (DOSTOIÉVSKI, 1962).

Em A Senhoria, Ordínov erra à procura de um lar temporário e, ainda que não se aperceba, garante que a religião, o misticismo e não a ciência balizem sua trajetória até o fim desta narrativa que, em síntese, assim como Noites Brancas, pode ter-se originado da experiência fantástica da personagem de Dostoiévski, frequentemente descrita como adoentada, acamada, presa de pesadelos e alucinações.

Uma vez imerso em um mundo de mistérios, na casa em que passou a habitar após concluir suas andanças, afastando-se sempre em direção à mais desgraçada periferia, o flâneur dostoievskiano de $A$ Senhoria não pôde mais render-se à desagregadora ciência moderna. Sem sucesso, dá voltas no quarto, tenta concentrar-se em seus pensamentos, tenta envolver-se nas doutrinas às quais tem acesso em seus livros, mas tudo o que consegue é achar-se num estado de semiconsciência, de modo que permaneciam as impressões dos últimos dias, desfilando diante de seus olhos num cortejo nebuloso ${ }^{46}$ e no qual distinguia a figura de seu algoz, o velho Múrin, esposo de sua nova senhoria, Ekaterina. Como um gnomo zombeteiro, associado depois por Ordínov às memórias da infância e às velhas crenças populares, Múrin tornou-se para ele, não sem razão, a personificação do mito, das crendices populares, da bruxaria e do espanto que é capaz de causar ao materializarem-se na forma de homem.

46 Idem, p.344. 
No plano da linguagem, há um efeito impressionante causado pelo confronto entre os mundos de Ordínov e Múrin, bem como entre o de Ordínov e Ekateriana. Esse confronto parece associado ao tecido social petersburguês, o mesmo narrado por Púchkin em $A$ casinha solitária da ilha Basílio. ${ }^{47}$ Segundo Púchkin, quem teve ocasião de dar um passeio em redor da Ilha Basílio, em Petersburgo, observou que seus extremos se parecem muito pouco, pois enquanto, segundo o autor, a orla oriental ergue-se com uma suntuosa fileira de enormes edifícios de pedra, a parte setentrional, em frente da ilhota de Pedro, constitui-se de raros edifícios que cedem lugar a casebres de madeira, descampados, barrancos, uma ou outra casinha solitária e escasso arvoredo (PÚCHKIN, 1980). Assim como Púchkin, Dostoiévski também descreve o bairro de Múrin e Ekaterina de modo que, ao leitor, pareça inóspito. Segundo ele, em suas andanças Ordínov chegou a um bairro da cidade muito afastado do centro. Passou por uma série de casebres cinzentos, acachapados, a que se seguiam uns edifícios menores que, em virtude da fuligem e altas chaminés, julgou serem fábricas. O ambiente em torno parecia-lhe morto, abandonado, hostil. ${ }^{48}$ Embora Ordínov seja um pobre diabo (membro de uma nobreza muito decaída), Múrin é de uma classe social muito inferior à dele e, por isso, refere-se ao locatário, em fins de conta, fazendo uso de expressões que denotam deferência, e certa ironia, como gosudar ou sudar, ${ }^{49}$ traduzidas em português apenas como "senhor". Além de expressar-se polidamente e um tanto afetadamente em relação ao rapaz, sua fala é muito frequentemente, assim como a de Ekaterina, coloquial, metafórica, repleta de imagens poéticas.

A maneira como articulam suas falas, o ambiente exotérico no qual vivem, a fé praticada por eles de maneira ritualisticamente obscura, compõem não apenas um cenário primordial e místico, mas também, por isso mesmo, um cenário popular,

47 PÚCHKIN, A. Contos Breves. Rio de Janeiro: Otto Pierre editores, 1980.

48 DOSTOIÉVSKI, F. Noites Brancas e Outras Histórias. Tradução de Vivaldo Coaracy, Rio de Janeiro: José Olympio. 1962. p. 330.

49 Trata-se de um termo arcaico, de pouco uso na época de Dostoiévski e frequentemente utilizado com intenção irônica. A forma menos irônica seria gospodim. Nota explicativa de Pavel Golubtsov. 
camponês. Entre homens e mulheres pobres parece haver, em Dostoiévski, um certo grau de misticismo popular mais preservado e oposto ao magnetismo ocidentalista, contrário ao movimento eslavófilo do qual Dostoiévski tomara partido em suas produções. Segundo o eslavofilismo, movimento cultural que está na base da revolução russa do século passado, "o espírito russo nunca poderia fundir-se com o espírito europeu devido às diferenças inconciliáveis que os separam, pois enquanto o primeiro se baseia na fé, o segundo se baseia na lógica, na razão". ${ }^{50}$ Embora não seja um anti-herói, Ordínov, metaforicamente, representa a lógica, a razão, e Múrin e Ekaterina, a fé, o misticismo, às vezes obscuro, intangível, espectral. O fator imprevisto, fantástico, sobrenatural também está presente na Casinha Solitária da Ilha Basilio, e reforça o enraizamento da cultura popular entre aqueles privados de acesso à cultura do ocidente, para os escritores russos, genuínos portadores do eslavofilismo mais intrínseco.

Em que pese, as grandes cidades e a vida de seus habitantes são de papel definitivo nas obras de Dostoiévski. Elas conformam seus heróis a um estilo de vida, a um projeto de sociedade que é não apenas controverso do ponto de vista de sua questionável eficácia, mas determinante no esfacelamento dos vínculos que ataram os homens à tradição. Se em Niétotchka Niezvánova observa-se o declínio da inocência, das relações familiares duradouras em troca do fortalecimento de relações efêmeras e degradação moral, é em Humilhados e Ofendidos ${ }^{51}$ que Dostoiévski os inaugura em seu projeto de escrita mais robusto. Ali, a cidade de São Petersburgo causa enjoo. Nos subúrbios, os Petersburgueses se amontoam, se prostituem, acobertam delitos, cafetinam crianças inocentes, jogam, negociam e tiram proveito da morte. Das desprezíveis relações que estabelecem, se alimentam. Também se alimentam do medo, do ódio, da vaidade, do dinheiro, das artes e da prostituição da arte, porque tudo ali estava envolvido em um grande esquema de prostituição.

50 DOSTOIEVSKI, F. Humilhados e ofendidos. Tradução de Rachel de Queiroz. Rio de Janeiro: José Olympio, 1962. p. 112.

51 Idem. Passim. 
Para compor a trama de Humilhados e ofendidos, Dostoiévski escolheu um jovem escritor como protagonista. Seu nome é Ivan Petróvitch, e não é por acaso que frequentemente associem-no a Dostoiévski. Em diversas ocasiões, sobretudo nos primeiros capítulos, o autor faz alusões ${ }^{52}$ a Pobre Gente como se se tratasse de um romance escrito por $\operatorname{Ivan}^{53}$ e a pessoas de seu círculo social, como se se tratassem de pessoas ligadas a ele, como ocorre por exemplo ao referir-se a Belinski, ${ }^{54}$ importante crítico de literatura da época e principal responsável por criticar e publicar as primeiras obras de Dostoiévski. Desde sua primeira publicação como folhetim no número inicial da revista $O$ Tempo (Vrêmia), o romance fascinou os leitores, que reconheceram no texto a possibilidade de se narrar os sentimentos mais obscuros com uma intensidade jamais vista. Sobretudo, daquele momento em diante, Dostoiévski consolidou-se como um tipo de "realista sentimental", mais compassivo, terno, embora ainda agudo, preciso no reconhecimento das mazelas e de seus desdobramentos sociais.

Em Humilhados e Ofendidos, o flâneur de Dostoiévski não é um eremita, como o Sonhador, ou um eremita esfarrapado como Makar. Também não é um Dândi, ${ }^{55}$ pomposo, elegante, frequentemente associado por Dostoiévski à noite e à prostituição, como ocorre em Crime e Castigo e Humilhados e Ofendidos. Ivan se parece mais com Ordínov, porém é mais profundo e mais bem-acabado. É erudito, possui boas relações e, sobretudo, boas pernas, para recuperar, uma vez mais, A Fisiologia do Flâneur.

Habitualmente, o narrador personagem de Humilhados e Ofendidos se serve de chá em uma confeitaria alemã na qual se distrai analisando os tipos (estranhos familiares) com os quais não chega a estabelecer relações, mas com os quais acostumara-se a encontrar àquela hora do dia. Dentre todos os frequentadores do café, um personagem frequentemente lhe

52 Idem, p.183.

53 Idem, p. 25.

54 Idem, p.52.

55 Idem, p. 111. 
chama atenção, trata-se de Smith, um velho imigrante, demasiadamente magro, de aspecto enfermiço, vestes rotas e acompanhado de um cachorro, o igualmente magro e desvalido Azórka. No interior da confeitaria, sentado a um canto, o miserável Smith metaforiza a decadência das ruas pelas quais vagueia. É a personificação do ocaso, da miséria do imigrante. A curiosidade de Ivan em relação ao estranho andarilho é acentuada após a morte de Azórka, no interior do estabelecimento abandonado às pressas por Smith. Tendo Ivan se lançado, como um flâneur prototípico, numa empreitada detetivesca ao encalço de Smith, e como se os destinos de homem e cão estivessem conectados, Ivan encontra-o caído, semiconsciente, na sarjeta. Ao escutá-lo balbuciar qualquer coisa acerca de um endereço, Ivan para lá se encaminha e adentra o apartamento no qual o velho morara até sua morte, minutos antes. Lá, conhece a pequena Helena, neta de Smith, que ao avô fora visitar. Ao saber de sua morte, se emociona e sai do apartamento sem que Ivan pudesse lhe falar mais apropriadamente. Dias depois, uma vez mais se encontram e dessa vez discorrem não apenas acerca da morte do velho, mas também acerca da orfandade da pobre menina. Temeroso pela segurança da garota, Ivan lhe oferece uma condução até a casa da mulher que a acolhera após a morte da mãe, a velha Bubnóva. Assentindo, em princípio, com o pedido da garota de que a deixasse longe de casa, mas rapidamente mudando de ideia em virtude da sensação de perigo despertada pelo aspecto do bairro habitado pela menina, Ivan a segue de longe e a vê adentrar uma vila paupérrima. No pátio, é agredida pela velha que a achincalha e humilha por ser órfã e viver às suas custas. Não suportando tamanha estupidez, Ivan intervém em favor da garota, mas de nada adianta, a velha possui, temporariamente, a guarda informal da criança. Naquele ambiente deletério, vizinhos fabricam e vendem caixões e é com mau presságio que o leitor de Dostoiévski recebe todas essas infelizes impressões aclimatadas pelo aspecto geral da cidade, descrita por Dostoiévski como sendo escura, úmida, suja e repleta de passantes tristes, aborrecidos e ensopados pela chuva. ${ }^{56}$

56 Idem, p.52. 
No caminho de volta para casa, Ivan se encontra com um velho companheiro do Ginásio do Governo, Maslobóiev, que, embora não fale abertamente do que se trata, sugere que Bubnóva, conhecida de todos os rapazes que, assim como ele, estão envolvidos em negócios escusos, tinha a intenção de cafetinar a pobre Helena. Infelizmente, para a criança, sua tese se confirma quando Ivan, Maslobóiev e alguns conhecidos, dentre eles um controverso Dândi, Sizobriúkhov, invadem a casa de Bubnóva e lá encontram a garota, prestes a ser violada. Após grande confusão e, tendo-a recuperado das mãos de Bubnóva, Ivan a leva para casa.

Trata-se de uma "história sombria, uma dessas histórias tenebrosas e pungentes que se desenrolam com tanta frequência, despercebidas e misteriosas, sob o pesado céu de Petersburgo, nos lôbregos, escondidos tugúrios da enorme cidade, a meio das efervescências atordoadoras da vida, dos fundos egoísmos, dos interesses que se chocam, da repugnante perversidade e dos crimes sangrentos; a meio daquele inferno de uma vida desenfreada e anormal...". ${ }^{57}$

$O$ arremate da narrativa é, como se sabe, um tanto inesperado, mas o enredo se desenlaça muito à moda de Dostoiévski: uma felicidade relativa e uma porção incalculável de humilhações mal resolvidas.

O flâneur dostoievskiano de Humilhados e Ofendidos é, embora seja também o mais detetivesco dos heróis dostoievskianos, o menos obscuro, sobretudo porque ao longo da narrativa vai ganhando contornos mais suaves, diferentes das primeiras impressões causadas por ele ao leitor. Essa diferenciação na maneira de apreendê-lo ocorre, principalmente, porque Ivan transita entre dois universos muito distintos: um é o tipicamente urbano, sujo, obscuro, marcado pela prostituição, pela morte e violência, o outro a Petersburgo comezinha, das relações sociais artificiosas, polidas e viciadas.

Como produto da sociedade burguesa, o flâneur é também produto de um mundo de contrastes que se chocam e se interpenetram. Nesse sentido, Ivan, assim como Raskólnikov, de 
Crime e Castigo, são os mais bem-acabados flâneres de Dostoiévski, e suas existências metaforizam o opróbrio do burguês semiperiférico. Humilhados e ofendidos, esses seres cuja natureza rebaixada à abjeção se revela, muitas vezes, superior à torpeza moral da elite do antigo regime monárquico russo, perambulam pela cidade, ali adoecem e têm sua virtude convertida em um caos que, em Dostoiévski, é levado às últimas consequências.

Em Crime e Castigo, o flâneur dostoievskiano beira à demência. O caos mental no qual Raskólnikov se enreda ao longo da narrativa é perturbador. Com ele, o autor penetra a mais sombria parte da alma humana na qual misturam-se paixões avassaladoras, instintos e desejos elementares. Através deles, Dostoiévski detecta e fixa os aspectos mais repugnantes da vida humana, encontrando nisso o prazer atormentado da autodestruição e do sofrimento como tábua de salvação. Como se se tratasse de um desdobramento da duplicidade de Golyadquin revisitado, em Crime e Castigo, em toda a sua potência, a destruição dos outros e de si próprio leva Ralkólnikov à completa, porém não irremediável, desagregação de sua personalidade.

Esfarrapado, o flâneur dostoievskiano de Crime e Castigo se deixa seduzir por uma tese científica segundo a qual lhe é outorgado o direito de matar sem, contudo, considerar-se assassino. É o primeiro dos heróis dostoievskianos - a Raskólnikov se seguirão Ivan Karamázov e seu irmão espúrio, o anti-herói Smerdiákov -, a se ver no limite entre o bem e o mal ao optar por levar adiante a doutrina destrutiva, embora paradoxalmente filantrópica e libertadora, da qual se ocupa e segundo a qual é permitido, a todo indivíduo que tenha consciência da verdade, regularizar sua vida como bem entender, de acordo com os princípios inovadores da época. Ainda segunda essa crença, diante da ausência de Deus e da imortalidade da alma, cabe ao homem, ao qual tudo é permito, de coração leve, libertar-se das regras da moral tradicional, às quais estava sujeito como um escravo.

Embora o comportamento inicial de Raskólnikov faça endosso à crença propalada pelos niilistas mais radicais, sua 
tese vai um pouco mais além, sobretudo por considerar-se superior aos demais, inclusive sobre os demais "livre pensadores" aos quais frequentemente se refere. Raskólnikov é, embora piedoso, compassivo e atento às necessidades humanas, extremamente vaidoso e, paradoxalmente (não para alguém cujo nome faz alusão à duplicidade, ao corte, à ruptura), egocentrado. O herói dostoievskiano de Crime e Castigo mata para demonstrar para si mesmo o limite de sua liberdade individual e sua excelsa extraordinariedade. Para os seus, é preciso que um homem possa manter-se, acima de tudo, fiel a si próprio. Fidelidade, oposta ao modelo de progresso ocidental. ${ }^{58}$ Como um confuso "homem-deus", ${ }^{59}$ cabe a ele tirar a vida, perdoar, remitir transgressões, compadecer-se, mas, também, ao ajoelhar-se diante de Sônia, reconhecer sua insignificância perante a grandiosidade do sofrimento humano.

Dos flâneres de Dostoiévski, Raskólnikov é o que melhor reúne as três características mais relacionadas a essa paradigmática figura moderna: sua associação indireta com a prostituição física e intelectual, sua miséria econômica (membro de uma baixa extração da burguesia), e sua imperativa necessidade de deslocar-se apresentando ao leitor, enquanto consolida sua demência, as ambientações às quais está familiarizado.

Assim como procede ao introduzir o Sonhador, Ordínov e Ivan aos leitores, o faz Dostoiévski ao introduzir-lhes Raskólnikov: andarilho, esfarrapado, prenhe de desejos. Tal como os demais, ele é muito jovem, sonhador. Curiosamente, pois assim também são apresentados ao leitor um sem número de heróis dostoievskianos (além dos supracitados), Raskólnikov não é nascido na capital russa do século XIX. Ao estudar o herói de Gógol, autor muito frequentemente associado à figura do flâneur, Markovich ${ }^{60}$ se apercebe de um elemento definidor que seria transmitido, mais adiante, a Dostoiévski: através de

58 DOSTOIÉVSKI, F. Crime e Castigo. Tradução Levon Yacubian. São Paulo: Nova Cultural, 2002. p. 187.

59 DOSTOIÉVSKI, F. Obra Completa, Os irmãos Karamazov. Rio de Janeiro: José Aguilar Editora, 1975. p. 1004.

60 MARKOVICH, V. Peterburgskie Povesti N. V. Gogolya. Leningrad: Khudozhestvennaya Literatura, 1989. 
seus heróis, Gógol pôde expressar inocente e vulgarmente as impressões visuais de um provinciano, que ainda não se fundira totalmente com o mundo de São Petersburgo, mantendo uma conexão implacável com algo primordial e antigo do que resulta sua agudeza especial de olhos. ${ }^{61}$

O flâner dostoievskiano é, assim como o de Gógol, nascido e criado no interior da Rússia, por isso está sempre deslocado, é provinciano, inocente, um tanto vulgar, e está sempre à parte do convívio social, do que muito tira proveito em suas andanças e singular capacidade de observação dos espaços públicos e privados pelos quais se desloca como um fantasma.

$O$ fato de que tenham nascido no interior da Rússia não contribui apenas conjecturalmente para que se tornem flâneres. Para Dostoiévski, essa relação é tão imediata que mal pode conceber a possibilidade de que, do interior, eles não sejam. Por isso, em "Zuboskal", 62 texto na época censurado, Dostoiévski admite haver talvez apenas um único flâneur petersburguês, um jovem ao qual chama de Zuboskal, "escarnecedor". Provavelmente, por se tratar de um nativo de petersburgo, o que é de imediato destacado pelo narrador como se tratando de um aspecto muito fundamental e particular de sua existência, Zuboskal é diferente dos demais flâneres de Dostoiévski. É um gozador, se entretem com o que é sério. Aliás, para ele, nada é sério. Não é tão melancólico, não circula preferencialmente pelos cantos e subúrbios imundos da capital russa, mas, como os outros flâneres de Dostoiévski, Zuboskal tem um tempo vasto e lugar nenhum para o qual, obrigatoriamente, precise ir. ${ }^{63}$

Já dissemos que ele não atende em lugar nenhum, não está familiarizado com nenhum departamento, com nenhum escritório, departamento, diretoria e arquivo[...] Acrescentemos que ele é um caminhante incansável, um observador, furtivo, se necessário, e conhece sua Petersburgo como a palma da mão. Você o verá em todos os lugares - no teatro

61 Idem.

62 DOSTOIÉVSKI, F. Zuboskal. São Petersburgo: Sankt-Peterburg v Topografii i Glazunova, 1845.

63 Idem. Passim. 
e na entrada do teatro, e em camarotes, e nos bastidores, e em clubes, e em bailes, e em exposições, e em leilões, e na Avenida Nevsky, e em encontros literários, e até mesmo lá, onde você não esperaria vê-lo de forma alguma - nas ruas de menor importância e nos cantos de São Petersburgo. Ele não despreza nada. Ele está em toda parte com seu lápis e seu lornhão e uma risada fina e vivaz. E aqui está outra vantagem do "Zuboskal": a primeira coisa e a coisa mais importante para ele é a verdade. A verdade antes de tudo. "Zuboskal" será um eco da verdade, uma trombeta da verdade, permanecerá dia e noite pela verdade e ela será sua fortaleza. ${ }^{64}$

Raskólnikov, assim como os demais provincianos flâneres de Dostoiévski, sofre em decorrência da realidade que, às suas mais belas inclinações, na cidade grande, acachapa. A cidade de São Petersburgo torna-se para ele não apenas a devoradora de suas aspirações mais subjetivas, mas a conversora de suas aspirações não em zero, como unidade matemática que indica uma certa quantidade cujo valor ascendente pode ser rastreado, mas à nulidade, como medida de coisa absolutamente vazia, desconhecida, nunca antes aplicada. A anulação da existência subjetiva dos homens fortalece em Raskólnikov a tese de que precisa, imperativamente, afastar-se da grande massa inane de indivíduos. Suas atitudes, ao longo da narrativa, fazem acenos às mais atrozes formas de "desumano heroísmo", e não é difícil entender o porquê. Em uma sociedade que massificava como prerrogativa de sua própria existência e rebaixa a individualidade a um grão de areia numa organização monstruosa de coisas e de potências, ${ }^{65}$ não parece, ao ultrajado, haver alternativa senão o endosso à barbárie. Causa compaixão a situação financeira de Raskólnikov, o vazio de suas relações e aspirações. Suas justificativas frequentes por atrasos de pagamento, suas mentiras. Seu chapéu velho, roto, que contribui para que ele, como de costume, ao sair à rua, se torne alvo de zombaria; ele, uma rapaz estudioso, piedoso, compassivo ${ }^{66}$ e gentil.

64 DOSTOIÉVSKI, F. Zuboskal. São Petersburgo: Sankt-Peterburg v Topografii i Glazunova, 1845. p. 46. Tradução nossa.

65 SIMMEL, Georg. A Grande Cidade e a Vida do Espírito Lusofiapress. Tradução de Artur Morão. Covilhã, 2009. p. 17. 
Embora todos os eventos sejam rapidamente narrados, o andar de Raskólnikov é lento. ${ }^{67} \mathrm{O}$ rapaz, alheado de tudo, enquanto se desloca pelas ruas, mergulha em uma espécie de profundo indiferentismo. Só fala consigo próprio, ri das próprias piadas enquanto vagueia inebriadamente. Raskólnikov é um perfeito flâneur. Como um detetive ou um criminoso, deseja manter-se anônimo, incógnito em meio à numerosa população de Petersburgo, e ao se dar conta de que não o pode ser, em virtude da feiura de suas vestes e chapéu surrado, murmura desgostoso que o necessário é, precisamente, passar despercebido, e que uma ninharia como aquela (o chapéu roto e chamativo) poderia deitar tudo a perder de uma vez para sempre (DOSTOIÉVSKI, 2002). Para Raskólnikov, as coisas que parecem ferir seu arbítrio, seus desejos, restringir sua essência, são descritas, sempre, como sendo ninharias. O leitor, é claro, de antemão, percebe que se trata de um eufemismo, pois o rapaz deseja convencer-se da insignificância daquilo que a ele perturba e aproxima-o do ramerrão. Não é de se estranhar que, como os demais flâneres de Dostoiévski, o de Crime e Castigo não seja simpático ao convívio social, mas se porventura, por algum motivo, interessa-se por alguém ao ponto de desejar estabelecer quaisquer relações, analisa-o, e o escrutínio é minucioso. Isso ocorre, por exemplo, quando se encontra em uma taberna com o ex-conselheiro Marmieládov, pai de Sônia. É sintomático que, após ser inquerido por ele acerca de sua colocação profissional e, por isso mesmo, acerca de seu papel na sociedade comezinha de Petersburgo, de súbito tenha Raskólnikov experimentado o seu habitual sentimento hostil em relação à comunicação, tamanha sua aversão à banalidade.

A prostituição escancarada e dissimulada também empurra o flâneur para um tipo de existência que é incompatível com a magnanimidade de suas aspirações. A irmã Dúnia, por exemplo, pretende entregar-se a um corrupto e rico "benfeitor", Lújin, em apoio à pobre família. Ao analisar sua situação desalentadora, livre do quarto amarelo no qual estava instala-

ral, 2002. p. 427.

67 Idem, p. 9. 
do, depara-se com uma outra forma de depravação, uma jovem embriagada prestes a ser, uma vez mais, violentada. Enquanto o guarda chamado por Ralkólnikov faz censuras à pobre infeliz, Raskólnikov apressa-se em sair em sua defesa solicitando ao guarda que desvie sua atenção da jovem e saia em perseguição ao criminoso. Um instante depois, cindido, Raskólnikov já não se importa com o destino da pobre menina. ${ }^{68}$

Para além das evidentes formas de prostituição, Raskólnikov prostitui seus princípios em troca de uma ideia e se degrada enquanto define seus planos e metas, aproximando-se cada vez mais da loucura. Suas idas e vindas por lugares imundos aproximam-no do trapeiro, ${ }^{69}$ vivendo de restos, do refugo da civilização. Embora considere-se excelso, Raskólnikov desliza pelo esgoto, agrada-lhe as tabernas subterrâneas, os pátios sujos e hediondos, os mendigos esfarrapados, de todo gênero (DOSTOIÉVSKI, 2002). Ele é um pouco diverso de seus antecessores. É dono de um certo grau de entorpecimento, por isso, caminha pelas ruas, mas não sabe, ao certo, por onde; não sabe como volta para casa; não sabe presa de quais pensamentos esteve enquanto caminhou. Se antes fora frequentador assíduo das ruas e nelas se entreteve, o agravamento de seus caracteres mais fundamentais, quais sejam, a solidão, o alheamento, o comportamento taciturno, sorumbático, forçou-o ao desprazer, ao tédio, ${ }^{70}$ por isso acontecera-lhe muitas vezes regressar à casa sem se aperceber das ruas que percorria. ${ }^{71}$

Embora amodorrado, um tanto desconectado, entediado, Raskólnikov ainda é um flâneur, o mais dostoievskiano de todos os flâneres, por isso, em curtos lampejos, vê o mundo como se o contemplasse, afasta-se da realidade brutal e se deleita na distância, no tempo suspenso, na existência suspensa de um quase completo anônimo em meio ao caos da cidade.

68 Idem, p. 51

69 BENJAMIN, W. Obras escolhidas III. Tradução de José Carlos Martins Barbosa e Hemerson Alves Baptista. São Paulo: Editora Brasiliense, 1989. p. 78.

70 DOSTOIÉVSKI, F. Crime e Castigo. Tradução Levon Yacubian. São Paulo: Nova Cultural, 2002. p. 149.

71 Idem, p. 62. 
A solidão de Raskólnikov é tremenda e em diversas ocasiões, embora acentue a dele, Dostoiévski explora literariamente a de diversas outras personagens cujo distanciamento social é ou não proposital. O distanciamento de Raskólnikov é, como se pôde perceber até aqui, tão proposital quanto, por exemplo, o de Svidrigáilov, porém, em certo sentido, mais nobre. Enquanto Svidrigáilov, segundo ele, vítima de oportunismo quando muito jovem, ${ }^{72}$ deseja tornar-se anônimo em meio aos habitantes da cidade para, como um dândi, muito indiferente e elegantemente, desfrutar à vontade dos clubes, restaurantes e progressos, Rodión Raskólnikov deseja tornar-se anônimo porque apenas assim pode, quer em seu quarto amarelo ou nas ruas cobertas de fuligem, integrar-se a si próprio, conectar-se consigo mesmo e com a cidade de maneira superlativa, tornando-se parte dela sem contudo enraizar-se na indiferença, nos vícios, no ódio, em meio a forças econômicas e políticas muito opressoras, coniventes com o mal, cuja materialização se encontra, por exemplo, no opróbrio de Sônia, diante da qual, humildemente, se ajoelha. ${ }^{73}$ É o sofrimento de ambos que, para Raskólnikov, será capaz de redimi-los. ${ }^{74}$

A narrativa se encerra de maneira um tanto enigmática e faz alusão a um sofrimento maior que ainda está por vir. Sônia saberá esperar pelo flâneur dostoievskiano de Crime e Castigo, que se deitará aos seus pés, chorará e abraçará os seus joelhos. Ele aceitará um destino rasteiro, mas, afinal, redimido, livre de tudo o que houvera lhe aprisionado, embora o mundo permanecesse o mesmo, paradoxalmente, nunca antes visto.

Vis-à-vis os países europeus, cujo processo de modernização ocorreu no decurso de pelo menos cinco séculos, na Rússia isto se deu enquanto fenômeno do século XVII, que se acelerou ao longo do século XVIII e encontrou seu apogeu no século XIX, graças, principalmente, à maneira com que em São Petersburgo mimetizou-se os princípios de modernidade obsedados desde os tempos de seu fundador, Pedro, O Grande.

72 Idem, p. 264.

73 Idem, p. 299.

74 Idem, p. 389. 
A realização da obra civilizadora de Pedro se encarregou da introdução das indústrias, das artes e ofícios; da criação de um exército regular e de uma marinha, além da ocidentalização da classe dominante. $O$ destino prospectado para sua função enquanto capital, vitrine para os ideais de progresso econômico e de reconciliação com o ocidente determinou, em última análise, uma importante relativização das convenções artísticas, do ideal de arte única e do objeto artístico enquanto manifestação irrepetível, porque ali repetiu-se os êxitos e malogros arquitetônicos e paisagísticos do passado.

A exemplo dos modos de vida, da ciência e da arte, a literatura também foi enxertada nesse caldo cultural, convertendo-se, no entanto, e pouco a pouco, em ferramenta de oposição ao avanço da ordem hegemônica que ali a havia introduzido. Temas mais nacionais, aspectos da vida de porteiros, lacaios, cocheiros, cozinheiros, comerciários, notívagos e prostitutas foram privilegiados por uma elite intelectual, sofisticada do ponto de vista do pensamento e hostil às ideias conservadoras do Estado. O valor ético da confissão, da redenção dos pecados por meio da humildade e do sofrimento, a apologia à fraternidade universal e a crítica ao cientificismo, cabotinismo literário e ao socialismo importado tornaram-se marcas importantes dessa vertente literária, que escolheu considerar as contradições daquele conjunto de circunstâncias.

Tendo como preceito basilar a introjeção de discursos de ordem política, religiosa, social e filosófica, a literatura de Dostoievski ocupou-se, de maneira precursora, da voz de seres socialmente incompatíveis com o modelo hegemônico, e que se avultam de maneira preponderante em Pobre Gente, Noites Brancas, A senhoria, Humilhados e Ofendidos e Crime e Castigo; narrativas da juventude e da maturidade que invocam os conceitos de errância para que, no que tange à literatura, pudesse tornar-se parte integrante da antinomia moderna, prospectando, à vanguarda, um novo sujeito para estes novos espaço e tempo: o flâneur dostoievskiano.

O herói dostoievskiano, aqui denominado flâneur, em virtude de seu principal ofício, a flânerie, pôde, como poucos, suspen- 
der o tempo, reconfigurar o espaço, demarcá-lo segundo novos critérios, setorizá-lo em virtude daquilo que lhe dizia ao coração, revelando sua natureza inacabada, seus mundos ocultos, nuances mais ou menos obscurecidas e subterrâneas que funcionam como metáfora para o que configura o elemento mais perturbador da escrita de Dostoiévski: a preponderância do mundo inconsciente, o declínio do espiritual e o rompimento de tudo o que deveria ligar o indivíduo à sociedade.

\section{Referências bibliográficas}

BENJAMIN, Walter. Charles Baudelaire - Um lírico no auge do capitalismo. Tradução de José Carlos Martins Barbosa e Hemerson Alves Baptista. São Paulo: Brasiliense, 1989.

BERENSTEIN, Paola. Elogio aos Errantes. Salvador: EDUFBA, 2012.

DOSTOIÉVSKI, Fiódor. Crime e Castigo. Tradução de Levon Yacubian. São Paulo: Nova Cultural, 2002.

DOSTOIÉVSKI, Fiódor. Noites Brancas e Outras Histórias. Tradução de Vivaldo Coaracy. Rio de Janeiro: José Olympio, 1962.

DOSTOIÉVSKI, Fiódor. Noites Brancas. Tradução de Nivaldo dos Santos. São Paulo: Editora 34, 2007.

DOSTOIÉVSKI, Fiódor. Obra Completa. Rio de Janeiro: José Aguilar Editora, 1975.

DOSTOIÉVSKI, Fiódor. Pobre gente. Tradução de Natália Nunes. Rio de Janeiro: Aguilar Editora, 1963.

DOSTOIÉVSKI, Fiódor. "Zuboskal”. Revista científica e literária. São Petersburgo: Glazunov e Co, 1845.

FERGUSON, Priscilla. Paris as revolution: writing the nineteenth-century city. Berkeley: University of California Press, 1994.

HOFFMANN, E.T.A. A janela de esquina do meu primo. Tradução de Maria Aparecida Barbosa. São Paulo: Cosac Naify. 2010. HUART, Louis. Physiologie du flâneur. Paris: Aubert et Cie, 1841. 
LUKACS, Georg. A teoria do romance. Tradução de José Marcos Mariani de Macedo.

São Paulo: Editora 34, 2000.

WHITE Jr., Lynn. Medieval Technology and Social Change. Nova Iorque: Oxford university press, 1964.

MARKOVICH, V. Peterburgskie Povesti N. V. Gogolya. Leningrad: Khudozhestvennaya Literatura, 1989.

SIMMEL, Georg. A Grande Cidade e a Vida do Espírito. Tradução de Artur Morão. Covilhã: Lusofiapress, 2009.

TURBANOV, I. Flaneri N Gogolya i F Dostoevskogo. Literaturno-filosofski zhurnal. Disponível em: https://www.topos.ru/ article/literaturnaya-kritika/flanery-n-gogolya-i-f-dostoevskogo. Acesso em: 5 jun. 2021.

VOLKOV, Solomon. São Petersburgo: uma história cultural. Tradução Marcos Aarão Reis. Rio de Janeiro: Editora Record. 1997.

WILSON, Elizabeth. O flâneur Invisível. Uberlândia: Artcultura, v.7, n. 11, 2005.

Recebido em: 15/09/2021

Aceito em: 30/11/2021 